Yulia Bob Damayanti, Afriva Khaidir| Program Asuransi Usaha Tani Padi oleh PT. Asuransi Jasa Indonesia (Persero) di Kabupaten Solok

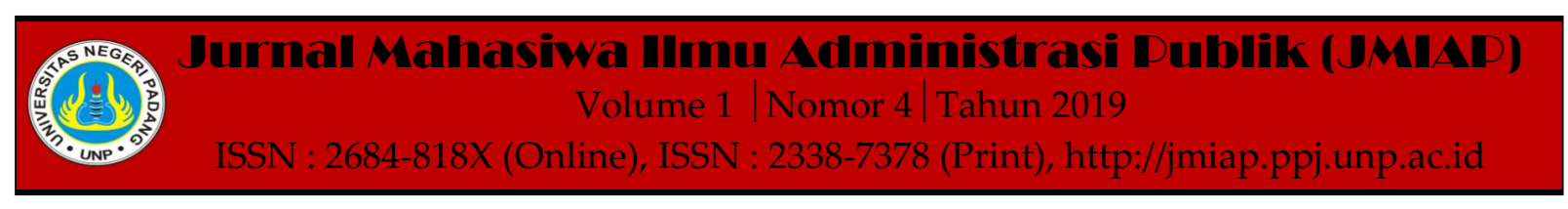

\title{
PROGRAM ASURANSI USAHA TANI PADI OLEH PT. ASURANSI JASA INDONESIA (PERSERO) DI KABUPATEN SOLOK
}

\author{
Yulia Bob Damayanti'(a), Afriva Khaidir ${ }^{2(b)}$ \\ ${ }^{1}$ Jurusan Ilmu Administrasi Negara, Universitas Negeri Padang \\ ${ }^{2}$ Jurusan Ilmu Administrasi Negara, Universitas Negeri Padang \\ a)yuliabobdamayanti@gmail.com, b)afrivak@yahoo.com
}

\begin{abstract}
The occurrence or failure of harvest that is felt by farmers in the planting season greatly determines the survival of farmers' daily lives. The purpose of this study is to see how the implementation of farm insurance by PT. Asuransi Jasa Indonesia (Persero) in solok Regency. The results of this study indicate that, first, there was a decline in the interest of farmers to participate in farm insurance in the next planting season, both human resources were insufficent in supporting farm insurance activities.
\end{abstract}

Keywords : Implementation, Rice Farming Insurance, Farm Risk

Corresponding author. Email.yuliabobdamayanti@gmail.com,afrivak@yahoo.com

How to cite this article. Damayanti, Y. Bob \& Khaidir, A. (2019). Program Asuransi Usaha Tani Padi oleh PT. Asuransi Jasa Indonesia (Persero) di Kabupaten Solok. Jurnal Mahasiwa Ilmu Administrasi Publik (JMIAP) Jurusan Ilmu Administrasi Negara Fakultas Ilmu Sosial Universitas Negeri Padang, Volume 1 (4), Hal. 79-86.

http://jmiap.ppj.unp.ac.id

ISSN : 2684-818X (Online), ISSN : 2338-7378 (Print)

Copyright $\bigcirc 2019$. Published by Pusat Kajian-Pemberdayaan dan Pelayanan Masyarakat (PK-P2M) FIS UNP Padang 
Yulia Bob Damayanti, Afriva Khaidir। Program Asuransi Usaha Tani Padi oleh PT. Asuransi Jasa Indonesia (Persero) di Kabupaten Solok

\section{PENDAHULUAN}

Indonesia merupakan negara yang dikenal sebagai negara agraris yang artinya negara dengan salah satu penunjang kesejahteraan masyarakatnya didalam sektor pertanian.Sebagian besar penduduk Indonesia hidup dari hasil bercocok tanam atau bertani.(Malthus, Thomas, 1978) dalam "An Essay on the Principle of Population" menyatakan bahwa kemiskinan yang dialami manusia karena merata nya pertumbuhan penduduk dengan peningkatan produksi pertanian.

Untuk menghindari risiko gagal panen yang lebih besar, pemerintah memberikan solusi untuk menanggulangi kerugian yang dirasakan petani saat gagal panen berlangsung yaitu asuransi usaha tani padi.terdapat di dalam Permentan No. 40 Tahun 2015 tentang Fasilitasi Asuransi Pertanian pasal 1 yang menjelaskan bahwa fasilitas asuransi tani. Asuransi tani adalah kemudahan dalam meringankan kerugian melalui perjanjian antara petani dengan pihak perusahaan asuransi untuk mengikatkan diri dalam pertanggungan asuransi." (Kementerian pertanian, 2015).Asuransi tani memiliki kesepakatan perjanjian antara petani dan pihak asuransi untuk mengikatkan diri dalam pertanggungan risiko usaha tani.

Nilai Premi yang ditanggung oleh petani yang akan ikut serta dalam pelaksanaan asuransi tani sebesar Rp. 36.000,00/Ha atau sekitar 20\% dari nilai asli premi sebesar Rp. 180.000,00. Pemerintah telah menyubsidi sisa premi yaitu $80 \%$ atau sekitar Rp. 144.000,00/Ha per petani. Untuk tahap awal asuransi pertanian difokuskan pada tanaman beras, karena beras merupakan makanan pokok masyarakat Indonesia secara umum.
Tabel 1. Laporan pelaksanaan AUTP di Kabupaten Solok Pada Tahun 2015-2018

\begin{tabular}{cccc}
\hline No. & Tahun & $\begin{array}{c}\text { Jumlah } \\
\text { Kelompok } \\
\text { Tani }\end{array}$ & $\begin{array}{c}\text { Luas } \\
\text { Lahan } \\
\text { Asuransi/ } \\
\text { Ha }\end{array}$ \\
\hline 1. & 2015 & 247 & $3,981.84$ \\
\hline 2. & 2016 & 96 & 964,88 \\
\hline 3. & 2017 & 14 & 134,72 \\
\hline 4. & 2018 & 72 & 867,44 \\
\hline Total & - & 429 & $5,948.88$ \\
\hline
\end{tabular}

(Sumber: Dinas Pertanian Kabupaten Solok tahun 2019)

Kenyataannya hasil penelitian pelaksanaan program asuransi tani di Kabupaten Solok diikuti oleh 12 kecamatan yaitu kecamatan Bukit Sundi, kecamatan IX Koto Sungai Lasi, Kecamatan Junjung Sirih, Kecamatan X Koto Diatas, Kecamatan X Koto Singkarak, Kecamatan Tigo Lurah, Kecamatan Hiliran Gumanti, Kecamatan Payung Sekaki, Kecamatan Kubung, Kecamatan Pantai Cermin, Dan Kecamatan Gunung Talang.

Asuransi usaha tani padi di Kabupaten Solok di laksanakan dari tahun 2015-2018. Penurunan minat kelompok tani sebagai peserta asuransi tani di Kabupaten Solok adalah penyebab utama dalam kelancaran pelaksanaan program asuransi tani di Kabupaten Solok, masih rendahnya tingkat kesadaran kelompok tani untuk ikut serta dalam program asuransi ini yang bertujuan memberikan bantuan asuransi kepada kelompok tani dalam mengatasi gagal panen. Pelaksanaan sosialisasi oleh Dinas Pertanian Kabupaten Solok menjadi faktor penting yang harus dilaksanakan secara rutin dan berkala agar asuransi tani ini berjalan sesuai target yang telah ditentukan oleh Dinas Pertanian Kabupaten Solok dan 
masih kurangnya kontribusi dari PT. Jasindo terhadap kinerja kelompok tani. Untuk itu dalam penelitian ini akan membahas tentang program asuransi usaha tani padi oleh PT. Asuransi Jasa Indonesia (Persero) di Kabupaten Solok.

\section{TINJAUAN PUSTAKA}

\section{Konsep Implementasi Kebijakan}

Menurut Van Meter dan Van Horn (Leo, 2012) menjelaskan pelaksanaan kebijakan dilaksanakan oleh setiap masyarakat, baik itu pejabat-pejabat atau kelompokkelompok pemerintah atau swasta yang diarahkan pada tercapainya tujuan yang telah digariskan dalam keputusan kebijaksanaan.

Efektifnya suatu perencanaan yang dilakukan oleh organisasi diharapkan tercapainya keberhasilan dan kepuasan masyarakat terhadap kebijakan tersebut (Frinaldi, 2019). Dengan kata lain hasil yang diharapkan akan sesuai dengan hasil yang dicapai (Witya \& Frinaldi, 2019).

Menurut (Frinaldi, 2018) mengatakan bahwa pembentukan program dapat berasal dari 5 (lima) dimensi yaitu jarak kekuasaan, individualisme-kolektivisme, maskulinitasfeminitas, penghindaran ketidakpastian dan orientasi jangka pendek jangka panjang. Pelaksanaan suatu program akan berjalan lancar apabila memiliki banyak fasilitas yang mendukung jalannya suatu program tersebut (Frinaldi, 2019). Penulis menggunakan indikator implementasi kebijakan menurut Brian W. Hogwood dan Lewis A. Gunn dalam Solichin Abdul Wahab (1991: 36) yang dimaksud dalam Formulasi ke Implementasi Kebijakan Negara yang mengemukakan sejumlah tahap implementasi sebagai berikut:

1) Tahap persiapan. Terdiri atas kegiatan yang menggambarkan rencana suatu program penetapan tujuan yang jelas, ada aturan pelaksanaan, dan rincian biaya yang dikeluarkan pada saat kegiatan berlangsung.
2) Tahap pelaksanaan. Kegiatan yang berhubungan dengan pelaksana/pegawai, sumber daya serta aturan dan persyaratan yang dipenuhi dalam kegiatan.

3) Tahap monitoring dan pelaporan. Penentuan jadwal kegiatan dalam menentukan jadwal untuk mengawasi saat kegiatan berlangsung.Sedangkan pelaporan hasil kegiatan untuk menjamin kelancaran pelaksanaan program. Dalam penelitian ini untuk mengukur faktor penghambat implementasi kebijakan menggunakan model Implementasi menurut George $C$. Edward III dalam Agustino (2012:50) yaitu:

a) Komunikasi. Komunikasi memiliki peran yang sangat penting dalam suatu kegiatan. Ada 3 cara untuk melihat keberhasilan suatu kegiatan dengan mengutamakan komunikasi, seperti:

- Transimisi, melakukan komunikasi yang baik dan tersampaikan kepada kegiatan yang akan dilaksanakan.

- Kejelasan, komunikasi yang diterima masyarakat harus jelas.

- Konsisten, perintah haruslah jelas dan konsisten. Menurut (Dwi \& Afriva Khaidir, 2019) informasi yang diberikan terhadap masyarakat terlihat tidak efektif apabila kebijakan tersebut tidak tepat dengan sasaran yang ditentukan.

b) Sumber Daya. Menurut Edward III dalam Agustino (2015: 151), indikator sumber daya terdiri dari:

- Staf. Kegagalan dalam pelaksanaan kegiatan disebabkan oleh jumlah staf tidak mencukupi dan staf yang dimiliki tidak sesuai dengan keahlian dalam bidangnya. Menurut (Frinaldi, 2016) dalam suatu wilayah atau negara perlu mendapatkan perhatian penuh untuk mewujudkan 
kebahagiaan dan kepuasaan masyarakat secara keseluruhan.

- Informasi. Pegawai harus tau apa saja informasi terbaru dan jelas yang akan diperintahkan.

- Wewenang. Pelaksana memiliki hak dalam melaksanakan kebijakan yang ditetapkan secara politik.

- Fasilitas. Harus ada fasilitas yang mendukung kelancaran suatu kegiatan yang diberikan untuk pegawai.

c) Disposisi. Tingkat keberhasilan implementasi kebijakan publik adalah disposisi. Adapun indikator dari disposisi yaitu:

- Pengangkatan

birokrat.

Pemilihan dan pengangkatan personil pelaksana kebijakan haruslah orang-orang yang memiliki dedikasi pada kebijakan yang telah ditetapkan. Apabila ada pegawai yang memiliki budaya kerja yang baik dan sesuai dengan aturan kerja, pastinya mampu melaksanakan pekerjaannya yang kritis (Frinaldi, 2018).

- Insentif. Kompensasi yang didapatkan oleh pelaksana mempengaruhi tindakan pelaksana.

d) Struktur Birokrasi. Terdapat dua kharakteristik dalam struktur birokrasi yaitu melakukan Standar Operating Prosedures (SOPs) yaitu suatu aturan yang berisi kegiatan sehari-hari pegawai yang telah disesuaikan oleh standar kegiatan yang telah ditetapkan sebelumnya. Sedangkan kegiatan fragmentasi adalah kegiatan yang diberikan kepada pegawai memiliki tanggung jawab atas kegiatan tersebut.

\section{Konsep Asuransi Usaha Tani Padi}

Penyelenggaran program asurani tani ini bermaksud untuk melindungi kerugian usahatani akibat gagal panen. Menurut
(Frinaldi, 2019) pengembangan kebijakan yang dilakukan oleh pemerintah bertujuan untuk meningkatkan kualitas dan kuantitas peningkatan kesejahteraan masyarakat Indonesia. (Djunedi, 1969) mengatakan bahwa tujuan penyelenggaraan program Asuransi Usaha Tani Padi adalah untuk memberikan perlindungan dan pengalihan kerugian kepada petani bila mengalami gagal panen yang disebabkan oleh banjir, kekeringan dan atau serangan organisme pengganggu tumbuhan.

Kriteria petani yang bisa mengikuti asuransi tani ini yaitu petani berskala kecil yang memiliki keterangan petani aktif dalam kelompok tani dan petani bersedia membayar premi sebesar Rp. 36.000,00,/Ha/Tnm dengan harga pertanggungan apabila terjadi gagal panen sebesar Rp.6.000.000,00/Hektar/Tanam serta lahan sawah yang diasuransikan maksimal 2 hektar baik itu yang petani yang menggarap dan yang mempunyai lahan sawah.

\section{METODE PENELITIAN}

Dalam penelitian ini peneliti menggunakan pendekatan kualitatif dengan metode deskriptif (Moleong. J. Lexy, 2006). Locus penelitian di PT. Asuransi Jasa Indonesia (Persero) Cabang Padang, Dinas Pertanian Kabupaten Solok. Penelitian ini menggunakan data yang didapatkan dari hasil wawancara, observasi, dokumentasi, dan uji keabsahan data dengan cara menggunakan teknik triangulasi sumber. Sedangkan untuk teknik analisis data dilakukan dengan cara reduksi data, penyajian data dan menarik kesimpulan.

\section{HASIL DAN PEMBAHASAN}

Dengan melihat tujuan dan manfaat dari adanya program Asuransi Usaha Tani Padi ini, sangat dirasa perlu sekali untuk bisa di akses langsung oleh petani. Brian W Hogwood dan Lewis A. Gunn dalam (Solichin, wahab, 2004:36) mengatakan dalam pelaksanaan suatu program memiliki tahapan-tahapan pelaksanaan sebagai berikut: 


\section{Tahap Persiapan}

Tahap ini mengambarkan rencana suatu program dengan penetapan tujuan secara jelas terdiri dari beberapa faktor yaitu kurun waktu, pencapaian sasaran atau target yang akan ditentukan.

Secara garis besar tujuan program asuransi tani adalah memberikan perlindungan asuransi kepada petani jika terjadi gagal paen sebagai akibat risiko banjir, kekeringan atau serangan hama. Dalam tahap ini dilakukan lah tahap persiapan berupa sosialisasi.Sosialiasi menurut Kamus Besar Bahasa Indonesia berarti upaya memasyarakatkan sesuatu sehingga dapat dikenal, dipahami dan dimengerti oleh masyarakat. Tujuan sosialisasi dalam program asuransi tani mengenalkan pada masyarakat mengenai program Asuransi Usaha Tani Padi sebelum dilaksanakan agar petani petani tertarik untuk ikut serta sebagai calon peserta program Asuransi Usaha Tani Padi tersebut. Asuransi tani di Kabupaten Solok dilaksanakan oleh Pegawai Penyuluh Lapangan didampingi oleh Pegawai bidang Sarana dan Prasarana Dinas Pertanian Kabupaten Solok dan Unit Pelaksna Teknis Daerah pertanian dari perwakilan kecamatan. Tahap sosialisasi dilaksanakan di awal tahun dengan cara mengumpulkan kelompok tani yang ada di Kabupaten Solok yang disesuaikan dengan target Asuransi Usaha Tani Padi ini dilaksanakan di 12 Kecamatan yang ada di Kabupaten Solok.

Namun dalam temuan peneliti dilapangan masih terdapatnya informasi dari kelompok tani bahwa masih ada sebagian dari kelompok tani tidak mendapatkan sosialiasi dari pelaksanaan program asuransi tani di Kabupaten Solok. Hal ini disebabkan oleh faktor komunikasi dan sumber daya yang ada di Dinas Pertanian Kabupaten Solok .

Hasil wawancara dengan narasumber bahwa dalam pelaksanaan sosialiasi ditemui kendala, antara lain pertama kurang dilakukan sosialisasi rutin sekali seminggu bersama ketua kelompok tani dan anggota kelompok tani yang dilakukan oleh beberapa Penyuluh Lapangan Dinas Pertanian Kabupaten Solok, Kedua, sumber daya seperti PPL Dinas Pertanian Kabupaten Solok dan PT. Asuransi Jasa Indonesia (Persero) yang kurang memadai bahwa berdasarkan wawancara dengan PPL yang melakukan sosialisasi dalam program Asuransi usaha tani padi hanyalah dari Dinas Pertanian Kabupaten Solok yang berjumlah 10 orang. Ketiga rendahnya minat serta keluhan kelompok tani setiap tahunnya dalam program asuransi tani ini disebabkan oleh tingginya syarat intensitas kerusakan apabila terjadi gagal panen yaitu diatas $75 \%$ oleh karena itu banyak keluhan dari kelompok tani. Keempat, kurang nya kontribusi PT. Asuransi Jasa Indonesia (Persero) terhadap kinerja petani di Kabupaten Solok karena dipersulit dalam melaporkan kerusakan apabila terjadi gagal panen.

\section{Tahap Pelaksanaan}

Kegiatan yang dilaksanakan harus mengikuti ketentuan dan prosedur yang telah ditetapkan sebelumnya. Temuan peneliti dalam pelaksanaan asuransi tani di Kabupaten Solok dilaksanakan berdasarkan Keputusan Menteri Pertanian RI Nomor 02/Kpts/SR.220/B/01/2016 tentang Pedoman Bantuan Premi Asuransi Usaha Tani Padi. Instansi yang terlibat didalam pelaksanaan asuransi tani ini diarahkan langsung oleh Kementerian Pertanian dan pelaksana nya yaitu Dinas Pertanian dan PT. Asuransi Jasa Indonesia (Persero)sebagai penanggung klaim asuransi.

Dalam tahap pelaksanaan dilakukanlah sosialiasi yang mencakup tentang pelaksanaan Asuransi Usaha Tani Padi dibantu oleh kelompok tani untuk mengkoordinir anggota nya yang ingin mendaftar sebagai peserta Asuransi Usaha Tani Padi dengan mengumpulkan syarat dengan menyetorkan luas lahan yang akan didaftarkan dengan menyerahkan 
Electronic-Kartu Tanda Pengenal (E-KTP) serta melakukan pembayaran premi yang sudah disetujui sebanyak Rp. 36.000,00,$/ \mathrm{Ha} / \mathrm{Tnm}$ dan di bayarkan melalui rekening kelompok tani yang dibantu oleh PPL dari Dinas pertanian Kabupaten Solok. Kemudian persyaratan terkumpul dan bukti pembayaran premi diserahkan langsung kepada PT. Asuransi Jasa Indonesia oleh Pegawai Penyuluh Lapangan.

Namun dalam Temuan penelitian pada tahun 2015-2018 pelaksanaan program Asuransi Usaha Tani Padi yang mencakup tentang pendaftaran peserta asuransi tani yang dilaksanakan oleh Pegawai Penyuluh Lapangan Dinas Pertanian Kabupaten Solok melakukan skema proses pendaftaran program Asuransi Usaha Tani Padi yang mulanya dilakukan secara manual seperti membagikan dan mengumpulkan berkas formulir pendaftaran dan apabila ada yang melaporkan kerusakan dilakukanlah pengumpulan berkas berita acara kerusakan. Tetapi pada awal tahun 2019, PT. Asuransi Jasa Indonesia (Persero) dan Dinas Pertanian Kabupaten Solok melakukan pendataan menggunakan Aplikasi Sistem Informasi Asuransi Pertanian, kendala yang peneliti dapatkan adalah Pegawai Penyuluh Lapangan mengalami kesulitan untuk melakukan pendaftaran calon peserta asuransi tani karena tidak semua Pegawai Penyuluh Lapangan paham dalam menggunakan aplikasi tersebut karena faktor umur Pegawai Penyuluh Lapangan $>40$ tahun.

\section{Tahap Monitoring dan Evaluasi}

Apabila monitoring yang dilakukan dengan baik akan bermanfaat dalam memastikan pelaksanaan kegiatan tetap pada jalurnya atau sesuai dengan pedoman dan perencanaan suatu program.

Dalam temuan penelitian, kegiatan monitoring dilaksanakan apabila ada laporan bahwasanya terjadi kerusakan yang disebabkan oleh risiko banjir, kekeringan dan serangan hama. Maka hal tersebut dapat dilaporkan kepada pengendali organisme pengganggu tumbuhan pengamat hama penyakit yang didampingi oleh Pegawai Penyuluh Lapangan dan pegawai dari PT. Asuransi Jasa Indonesia (Persero) untuk mengukur risiko kerusakan nya dengan intensitas $>75 \%$. Pelaporan kerusakan dilaksanakan dengan renggang waktu 7 hari kalender setelah diketahui terjadi nya kerusakan.

\section{Tahap Evaluasi}

Pada tahap ini dilakukan lah pelaporan terhadap kegiatan yang telah direalisasikan dalam pelaksanaan kebijakan. Hasil pelaksanaan asuransi tani padi di Kabupaten Solok yang peneliti dapatkan dari Dinas Pertanian Kabupaten Solok bidang Sarana dan Prasarana terlapor bahwa masih rendahnya kesadaran kelompok tani Kabupaten Solok untuk ikut serta dalam program Asuransi Usaha Tani Padi tersebut. Di kabupaten Solok terdapat 12 Kecamatan yang ditargetkan oleh Dinas Pertanian Kabupaten Solok untuk ikut serta dalam program Asuransi Usaha Tani Padi yaitu kecamatan Bukit Sundi, kecamatan IX Koto Sungai Lesi, kecamatan Junjung Sirih, kecamatan X Koto Diatas, kecamatan X Koto Singkarak, kecamatan Tigo Lurah, kecamatan Hiliran Gumanti, kecamatan Payung Sekaki, kecamatan Kubung, kecamatan Lembang Jaya, kecamatan Pantai Cermin, dan kecamatan Gunung Talang.

Pada tahun 2015 Dinas pertanian Kabupaten Solok menargetkan 6.500 hektar lahan sawah kelompok tani yang akan diasuransikan dalam 12 Kecamatan yang ada di Kabupaten Solok. Namun realisasinya hanya 247 kelompok tani yang ikut serta dalam programAsuransi Usaha Tani Padi ini dengan luas lahan yang diasuransikan sebesar 3.981.94 hektar.Pada tahun ini belum ada laporan pengajuan tuntutan ganti rugi kepada pihak asuransi. Pada tahun 2016-2018 Dinas Pertanian Kabupaten Solok memiliki target lahan yang diasuransikan yaitu 4000 hektar. 
Pada tahun 2016, kelompok tani yang ikut serta sejumlah 96 kelompok dengan luas lahan diasuransikan 964.88 hektar, dengan laporan total ganti rugi klaim yang telah terbayarkan kepada 22 kelompok tani yang mengajukan klaim yang berasal dari 4 kecamatan yaitu kecamatan Pantai Cermin, Kecamatan X Koto Singkarak, Kecamatan junjung Sirih dan Kecamatan Gunung Talang dengan total ganti rugi pembayaran sebesar Rp. 140.418.720,-. sedangkan ada 8 kelompok tani yang mengajukan klaim ditolak dengan keterangan yaitu pertama klaim tidak dapat di proses dikarenakan nama petani tidak terdaftar di dalam polis, kedua terdapat bukti kerusakan sudah dipanen/disabit, dan ketiga terdapat intensitas kerusakan kurang diatas 75\%.

Setelah itu, tahun 2017, realisasi program Asuransi Usaha Tani Padi ini diikuti oleh 14 kelompok tani dengan lahan yang diasuransikan 134.72 hektar.Kendala yang peneliti dapatkan dalam melakukan pendataan pengajuan klaim pada tahun ini yaitu tidak mendapatkan data rekapan pengajuan klaim oleh kelompok tani.

Sedangkan pada tahun 2018, program AUTP di Kabupaten Solok diikuti oleh 14 kelompok tani dengan luas lahan sawah sebesar 867.44 hektar, dengan laporan total ganti rugi tuntutan klaim yang terbayarkan berasal dari 2 kecamatan yaitu kecamatan Gunung Talang dan Kecamatan X Koto Singkarak dengan total ganti rugi klaim sebesar Rp. 17.750.400,- dan ada 3 kelompok tani dari Kecamatan X koto Singkarak mendapat keterangan penolakan klaim karena umur padi belum sampai 10 hari setelah musim tanam, sedangkan pengajuan klaim nya dilakukan saat padi baru berumur 2-4 hari.

\section{PENUTUP}

Program asuransi tani merupakan bentuk kebijakan sosial pemerintah dibahwa Kementerian Pertanian dalam upaya melindungi petani dari risiko gagal panen akibat serangan hama, kekeringan dan bencana alam. Program Asuransi Usaha
Tani Padi telah dilaksanakan sejak bulan Oktober 2015 di Kabupaten Solok.Kelompok tani yang yang ditargetkan oleh Dinas Pertanian Kabupaten Solok terdiri dari 12 kecamatan yang berada di Kabupaten Solok.Pelaksanaan progam asuransi usaha tani padi di Kabupaten Solok dapat ditarik kesimpulannya pertama Faktor Komunikasi, dalam implentasi program usaha tani padi di kabupaten Solok dalam melakukan sosialiasi belum tersalurkan dengan baik.Masih ada laporan dari sebagian kelompok tani kabupaten Solok yang belum mengetahui program asuransi usaha tani padi.

Kedua, faktor sumber daya manusia.pelaksanaan program asuransi tani adi di Kabupaten Solok belum memenuhi kapasitas untuk menunjang keberlangsungan program ini karena di dalam segi kuantitas, baik itu pegawai penyuluh lapangan dari Dinas Pertanian Kabupaten Solok dan pegawai PT. Asuransi Jasa Indonesia (Persero) kurang memadai.

Ketiga, faktor disposisi/sikap pelaksana, dapat disimpulkan sikap agen pelaksana PT. Asuransi Jasa Indonesia (Persero) belum terpenuhi karena masih banyak agen pelaksana yang tidak memiliki pemahaman di bidang pertanian.

Keempat, faktor birokrasi Struktur birokrasi di PT. Asuransi Jasa Indonesia (Persero belum terpenuhi karena agen pelaksana sudah mendapatkan SOPs tapi tidak merealisasikan program asuransi usaha tani padi di Kabupaten Solok.

\section{DAFTAR KEPUSTAKAAN}

Djunedi, P. (1969). Analisis Asuransi Pertanian di Indonesia: Konsep, Tantangan dan Prospek. Jurnal Borneo Administrator, 12(1), 9-27.

Dwi\& Afriva Khaidir. (2019). Efektivitas Program Desaku Menanti Bagi Warga Binaan.Journal of Multidisciplinary 
Yulia Bob Damayanti, Afriva Khaidir। Program Asuransi Usaha Tani Padi oleh PT. Asuransi Jasa Indonesia (Persero) di Kabupaten Solok

Reserch and Development, 1(2), 210217.

Frinaldi. (2018). Pengaruh Budaya Kerja Etnik Terhadap Budaya Kerja Keadilan dan Keterbukaan Pns dalam Membangun Masyarakat Madani dan Demokrasi (Studi pada Pemerintah Kabupaten Pasaman Barat). Humanus, $10(1), 52$.

Frinaldi, A. (2016). The Influence of Driver Work Culture and Service Quality on Citizen Satisfaction with Mass Transportation. 84(Iconeg 2016), 450453. https://doi.org/10.2991/iconeg16.2017.101.

Frinaldi, A. (2019). Policy Management to Develpo Tourism Work Culture Consciousness and Increasing Visiting People's Satisfaction. Journal of Government and Politics, 10(1), 4967.
Kementerian pertanian.Peraturan Menteri Pertanian Republik Indonesia NO. 40/Permentan/SR.230/7/2015. (2015).

Leo, A. (2012). Dasar-Dasar Kebijakan Publik. Bandung: Alfabeta.

Malthus, Thomas, R. (1978). An Essay on The Principle of Pupulation (6th ed.). Inggris.

Moleong. J. Lexy. (2006). Metodologi Penelitian Kualitatif (P. R. R. K. Bandung, ed.). Bandung.

Solichin, wahab, A. (2004). Analisis Kebijakan: Dari Formulasi ke Implementasi Kebijakan Negara (Edisi Pert). Jakarta: Bumi Aksara.

Witya \& Frinaldi. (2019). Efektivitas Implementasi E-Government Dalam Pelayanan Kependudukan di Dinas Kependudukan dan Pencatatan Sipil Kota Padang. Journal Of Multidisciplinary Reserch and Development, 1(3), 428. 